\title{
Semi Interlocking Masonry as Infill Wall System for Earthquake Resistant Buildings: A Review
}

\author{
Y. Totoev*, a and A. Al Harthyb \\ ${ }^{*}$ Centre for Infrastructure Performance and Reliability, University of Newcastle, New South Wales, Australia. \\ ${ }^{b}$ Civil and Architectural Engineering Department, College of Engineering, Sultan Qaboos University, Oman.
}

Received 20 January 2015; Accepted 30 August 2015

\begin{abstract}
Masonry is one of the most popular building materials. It has many excellent material properties and proven durability. Over time, masonry structures have evolved from massive walls, which work mainly through compression, to more slender walls, which could also experience tension and shear. Earthquake-induced tensile and shear stresses often exceed the capacity of traditional unreinforced masonry resulting in substantial damage and failure. A new mortar-less masonry system called semi-interlocking masonry (SIM) is presented in this paper. It has reduced stiffness and susceptibility to damage and utilized a special method of interlocking bricks that allows relative sliding of brick courses in-plane of a wall and prevents out-of-plane relative movement of bricks. The paper reviews the research on SIM to date and identifies new research opportunities in this area.
\end{abstract}

Keywords: Masonry, Wall, Interlocking masonry, SIM, Infill.

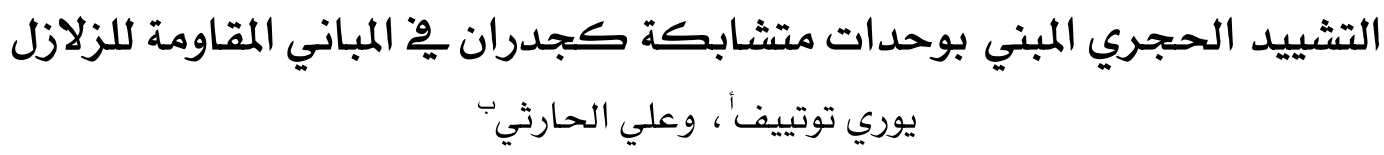

الملخص: تعتبر الهياكل الحجرية واحدة من مواد البناء الأكثر انتشارا وشعبية. إذ أن لديها العديد من الخصائص الممتازة والمتانة التي أثبتت جدواها. فمع مرور الوقت، تطورت هياكل البناء الحجرية من الجدران الضخمة المقاومة أساسـا لقوى الضغط إلى الجدران الرفيعة التي قد تتعرض أيضا إلى قوى الشد والقص. إن الهزات الزلزالية تتسبب بإجهادات شد وقص عالية التي عادة ما تتجاوز قدرة تحمل الجدران التقليدية الغير مسلحة بالحديد مما يؤدي إلى حدوث أضرار بليغة مع إخفاقها. وتم هُ هذه الورقة تقديم نظام جديد مطور للهياكل الحجرية. ويطلق على هذا النظام جدار شبه الأحجار المتشابكة الخالي من المؤنة الإسمنتية. وقد خفض هذا النظام التصلب والتعرض للأعطال. فهذه الجدران تستخدم أسلوبا خاصا من الطابوق المتشـابك التي تسمح لطبقة الطابوق بالانزلاق وْْ مستوى سطح الجدار وتهنع حركة خروج وحدات الجدار وِّ اتجاه خارج المستوى. وتستعرض هذه الورقة البحوث التي أجريت حتى الآن ِِّ موضوع جدار شبه الأحجار المتشابكة مع تحديد فرص جديدة للبحث ِِّه هذا المجال.

الكلمات المفتاحية: الهياكل الحجرية، الجدار، الطابوق المتشابك، جدار شبه الأحجار المتشابكة الخالي من المؤنة الإسمنتية، سد الفراغ.

* Corresponding author's e-mail: yuri.totoev@newcastle.edu.au 


\section{Introduction}

Masonry is one of the most popular building materials. It has many excellent material properties and proven durability. Over time, masonry structures have evolved from massive walls, which work mainly through compression, to more slender walls, which could also experience tension and shear. Earthquake-induced tensile and shear stresses often exceed the capacity of traditional unreinforced masonry resulting in substantial damage and failure. Reinforced masonry has better earthquake resistance; however, it is more expensive and requires expertise not always available in developing countries. The design of practical masonry with improved earthquake resistance still presents a challenge for structural engineers.

Oman and other countries in the Arabian Peninsula and Arabian Gulf are part of the Arabian plate that comes into collision at its northeastern margin with the Zagros Mountains of Iran and at the Indian Ocean in the east with the Makran Trench. These margins are marked by intense earthquake activities. For example, the 2008 Bandar Abbas earthquake measuring 6.3 on the Richter scale causing seven deaths and 30 injuries occurred only $100 \mathrm{~km}$ from Khasab, a town in the north of Oman. The destructive earthquakes of Sistan and Baluchistan in 2013, Bushehr in 2013 and Bam in 2003 occurred, respectively, at $425 \mathrm{~km}, 550 \mathrm{~km}$ and $1200 \mathrm{~km}$ from Khasab. The very destructive 2001 Gujarat earthquake on the western Indian coast occurred at about $1000 \mathrm{~km}$ from the coast of Oman. Earthquake monitoring in Oman and countries in the Gulf Cooperative Council (GCC) has started recently and earthquakes of even minor intensity have been felt and recorded (Qamaruddin and $\mathrm{Al}$ Harthy 2000). As the occurrence of an earthquake in Oman is probable, earthquake-resistant design provisions in building codes need to be prepared and used for buildings to resist earthquake loads, especially for important buildings such as hospitals, schools and telecommunication towers.

Buildings in Oman and many parts of the Middle East are made of reinforced concrete frame with infill masonry walls made of concrete blocks which, if properly designed and detailed, can resist moderate earthquake loads.
The first author of this paper has developed a new masonry system called semi-interlocking masonry (SIM). It has reduced stiffness and susceptibility to damage and an increased capacity to dissipate earthquake energy as compared with traditional masonry.

The main objective of this paper is to introduce SIM panels as an option for an earthquake-resistant framed masonry building. The paper will also summarize the research on SIM conducted to date, describe benefits of and problems with SIM and identify new research opportunities.

\section{Semi-Interlocking Masonry (SIM)}

SIM is an innovative building system for mortarless walls which utilizes a special method of interlocking SIM bricks that allows relative sliding of brick courses in-plane of a wall and prevents out-of-plane relative movement of bricks (Australian Patent Application No. 2010905681, 2010).

Two different methods of semi interlocking have been developed:

- $\quad$ using specially shaped bricks, or topological SIM and

- using conventionally shaped bricks with special perforations and dowels, or mechanical SIM (Fig. 1).

Traditional brick molding technology can be easily adopted for making topological SIM units. Mechanical SIM units are designed to utilize existing brick extrusion technology. The structural performance of these two SIM types is essentially identical (Wang et al. 2014). Topological SIM, however, appears to have better resistance to water penetration (Forghani et al. 2014).

Several possible structural and non-structural applications of SIM include

- infill panels in multistorey frame structures,

- walls in confined masonry structures,

- masonry skins of a reverse brick veneer system,

- robotically prefabricated masonry walls, and

- $\quad$ do-it-yourself (DIY) masonry.

There are many different interlocking brick/block masonry systems on the market. They have all been developed to build structural or nonstructural walls without mortar. Some of them are dry set like SIM; others use various adhesives to bond units into a monolithic wall. The main 


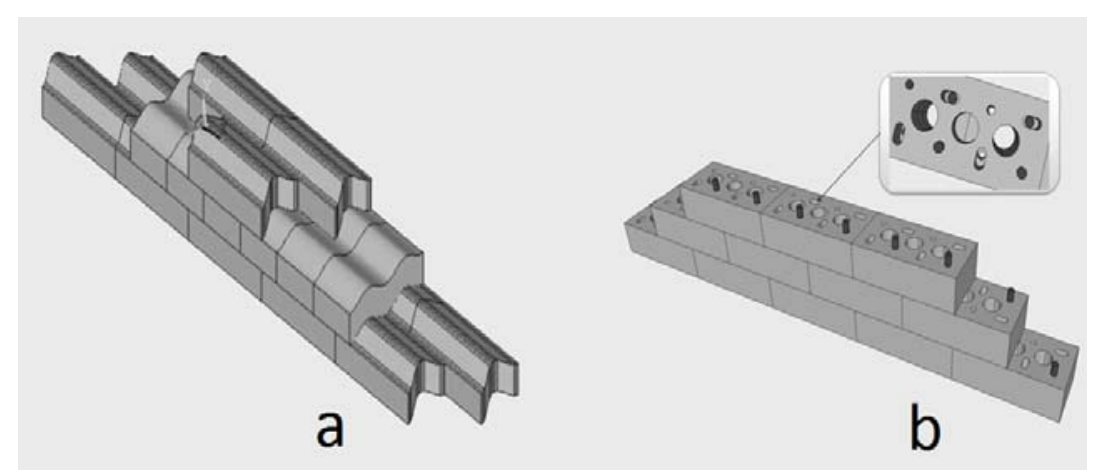

Figure 1. Different methods of semi interlocking: a. topological and b. mechanical (Totoev et al. 2014).

difference of SIM is that, unlike all of these systems, it avoids connecting units into a monolith. In fact, its purpose is quite the opposite: it makes walls pliable and deformable.

To better understand the novelty of SIM, recall the definitions of a structure and a mechanism. A structure is a body or an assembly of bodies that form a system capable of supporting loads. A mechanism is an assembly of moving parts capable of performing a complete functional motion. SIM is designed for the relative motion of bricks without necessarily supporting loads. Therefore, some SIM walls, including infill panels, are not structures but energy dissipating mechanisms. This paper discusses the use of SIM as infill panels in multistory frame structures.

\section{Structural Application of SIM as Infill Panels}

Semi interlocking masonry (SIM) is an innovative building system that uses engineered mortar-less masonry panels to improve energy dissipation of frame structures during earthquakes. The energy dissipation occurs through friction between bricks as they engage in relative sliding by the frame vibrating during earthquake. SIM panels are designed for inclusion in new earthquake-resistant structures as well as seismic rehabilitation or retrofitting of existing structures.

Traditional masonry infills are either architectural walls or structural panels designed to brace frame structures. They are not intended for energy dissipation. Energy dissipation in these infills during earthquakes mostly relates to microand macro-structural cracking and the plastic behavior of materials. The capacity of traditional infills to dissipate energy in this way before failing is quite limited.
The novel purpose of SIM infill panels is to provide frame structures with artificially added damping. In SIM panels, energy dissipation occurs mostly through friction between bricks of the panel. SIM is a unique system, which utilizes masonry infills as effective energy-dissipation devices (EDD) to improve the earthquake resistance of frame structures.

Superficially, a SIM infill looks like any other masonry infill panel. However, it is conceptually different from all other masonry infill types. Consider the classical equation of motion for a structure under earthquake load to demonstrate this difference:

$k \boldsymbol{u}+c \dot{\boldsymbol{u}}+m \ddot{\boldsymbol{u}}=-m \ddot{\boldsymbol{u}}_{\boldsymbol{g}}(t)$

where $\boldsymbol{u}$ is the vector of dynamic displacements (vibrations); $\boldsymbol{u}$ is the vector of velocities, $\ddot{\boldsymbol{u}}$ is the vector of accelerations, $\ddot{\boldsymbol{u}}_{\boldsymbol{g}}(t)$ is the acceleration of the ground, $\boldsymbol{k}$ is the stiffness matrix, $\boldsymbol{c}$ is the damping matrix, and $\boldsymbol{m}$ is the mass matrix. All common types of masonry infills structurally are various forms of frame bracing. They minimize vibrations mainly by increasing the stiffness of the structure represented in Eq. 1 above by the stiffness matrix. Often this is achieved at the expense of lowering the yield displacement and displacement ductility of the structure. SIM infills also aim to minimise vibrations but in a different way. Being energy dissipation devices, they achieve this objective by changing the damping matrix without detrimental effect on the yield displacement and displacement ductility of the structure.

The invented system in 2010 (Australian Patent Application No. 2010905681, 2010) was first introduced in print in 2011 (Lin et al. 2011). Various elements of it are not new. In fact, one could trace its heritage to the dry set stone masonry of the Mesolithic Era with elements of interlocking such as the mortise-and-tenon joints of Stonehenge. 
Another ancient example of topologically interlocking masonry is the multifaceted stones of Machu Picchu. Ancient Egyptians, Romans, Incas, and Khmers used metal masonry block connectors. Slotted holes are very common in steel construction for relative sliding of connected parts. The concept of a masonry wall designed not as a monolith structure but as a mechanism where bricks slide against each other is entirely new, however.

SIM does not possess self-recentering capability. Therefore, it could exacerbate the residual distortion of the frame after earthquakes. It would be advisable to combine SIM panels with other structural systems to reduce possible residual distortion.

\section{Previous Research on Dry Stack Masonry}

Some research has been done previously on dry stack masonry. Lourenco with his colleagues performed a series of tests (Lourenco et al. 2004; Lourenco and Ramos 2004) and concluded that the failure criteria of dry stack stone is a type of MohrCoulomb failure. A number of cyclic tests and shaking table tests both on dry stack stone and mortar stone wall were also carried out (Lourenco et al. 2005; Vasconcelos et al. 2006; Vasconcelos and Lourenco 2009). From those tests, the type of wall boundary conditions and the vertical compression level were confirmed as two important factors for the failure mode. Considerable nonlinear deformations were attained (storey drift of $2.5 \%$ ). However, because of the rocking failure mechanism, it was concluded that unframed dry stack walls were unable to dissipate energy.

Uzoegbo (2003) have researched both the inplane and out-of-plane seismic behavior of dry stack masonry wall (Uzoegbo et al. 2003; 2004). According to this research, the strength of dry stack units does not make a significant difference in the resistance to lateral loads; the interlocking and friction between units govern the lateral load bearing capacity. The compressive strength of the panel is directly proportional to the strength of masonry units. They also observed rocking of the dry wall before failure. A shake table test was conducted on the dry stack system, which demonstrated that the dry stack masonry structure could resist ground acceleration of up to $0.3 \mathrm{~g}$ (Uzoegbo and Senthivel 2009).

All previous research on framed dry stack masonry infills was conducted at the University of Newcastle in Australia and Harbin Institute of Technology (Shenzhen Graduate School).

\section{Research Results on SIM}

\subsection{Types of SIM Infill Panels}

A narrow gap between the top of a SIM panel and the frame girder is difficult to avoid during construction of panels within the frame. Special packing should be used when this gap is undesirable. The presence of this gap and its width play a key role in the structural response of SIM panels to earthquake-induced vibrations. There are three main types of SIM panels:

- SIM with open gap. This type of SIM panel is built hard against the columns but has a gap between the top of the panel and the girder (Fig. 3a). The frame interacts with the SIM panel only in trough columns. The gap does not close during earthquake-induced vibrations. Assuming a sin shape for deforming columns, the critical gap width $\boldsymbol{d}_{\text {gap }}$ can be calculated as illustrated in Fig. 2.

$$
\begin{aligned}
& l\left(\sin _{0 \rightarrow x}\right) \approx \frac{45}{37} x \frac{3}{29} \sin 2 x-\frac{x}{4796} \\
& l(\sin \pi) \approx \frac{45}{37} \pi+0-\frac{\pi}{4796} \approx 3.82 \\
& d_{\text {gap }}=l_{a b}-h_{a b}=3.82 \frac{\Delta_{u l t}}{2}-\pi \frac{\Delta_{u l t}}{2} \cong 0.34 \Delta_{u l t}
\end{aligned}
$$

where in Eq. $4, \Delta_{u l t}$ is the ultimate storey drift, $l_{a b}$ is the length of distorted column $\boldsymbol{a b}$, and $\boldsymbol{h}_{\boldsymbol{a}}$ is its height.

For a SIM infill panel with the gap always open, its width must conform to the following conditions: $d_{\text {gap }} \geq 0.34 \Delta_{u l t}$.

Frame girders never clamp a SIM panel of this type in a vertical direction. It provides mainly energy dissipation to the structure. Its strengthening effect is limited to the maximum friction force developed on the bead joints of the panel due to self-weight.

- SIM without a gap. There are no gaps between this type of SIM panel and the frame. It is in contact with the girder as well as columns (Fig. 3b)

$$
d_{\text {gap }}=0 \text {. }
$$

Therefore, panels are clamped between girders at all amplitudes of vibrations. This has the dual effect of providing some bracing to the frame 


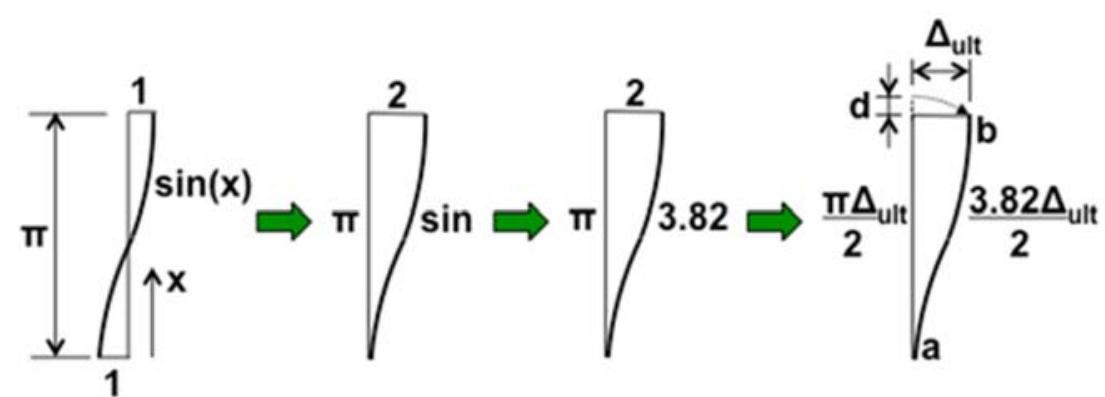

Figure 2. Estimation of the critical gap width above a SIM infill panel.

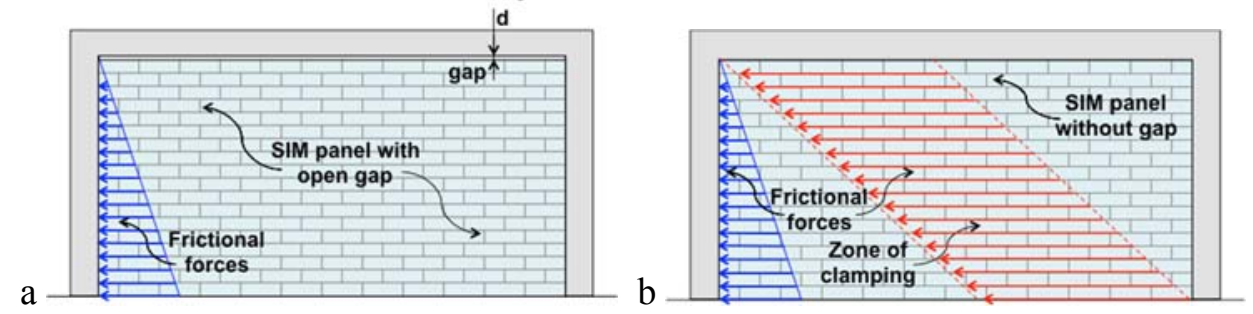

Figure 3. Different types of SIM panels displaying a) With an open gap and b) Without a gap.

through the diagonal clamping zone and providing a higher level of energy dissipation compared to the previous type of SIM panel due to higher compression/friction on the bead joints.

- SIM with a closing gap. This is a combination of the first two types. It has a very narrow gap between the top of the panel and the girder

$0<d_{\text {gap }}<0.34 \Delta_{\text {ult }}$

This type of SIM panel provides mainly energy dissipation to the structure during small amplitude vibrations when the gap remains open. However, as the amplitude increases, the gap closes, the clamping is activated, and the panel begins to provide additional bracing to the frame as well as higher energy dissipation.

Vertical post-tensioning of SIM panels through regular perforations in bricks could have several benefits to structural performance. To illustrate these let us consider the SIM with open gap type panels. Post-tensioning would increase compression on the bead joints and, therefore, friction between bricks; increase the bracing capacity of the panel; allow the design of a SIM panel for a certain slip load, and improve out-ofplane stiffness and the strength of the panel.

\subsection{Experimental Work}

Initial tests on SIM have included compressive tests on SIM units and SIM prisms. Cyclic friction tests on SIM triplets (Lin et al. 2012) [Fig. 4a] were performed on prototype mechanical SIM units using a modified triplet shear test (I.O.F. prEN1052-3, 1993). An average friction coefficient of 0.66 was determined for concrete units at a clamping stress of $0.1-0.5 \mathrm{MPa}$. However, at higher levels of clamping stress, the friction coefficient reduced to 0.55 . This value is recommended for analysis as it is more conservative. In-plane cyclic displacement tests were performed on the full-scale reduced size RC frame infilled with the prototype mechanical concrete SIM with a closing gap panel ( $2 \times 2 \mathrm{~m}$; type $3 ; 227 \times 113 \times 80 \mathrm{~mm}$ concrete units) [Fig. 4b]. Detailed results are reported in Kun et al. (2011) and Lin et al. (2011a). These tests identified three main response mechanisms for a frame with a SIM infill panel: constant friction response, the Mohr-Coulomb response, and a plastic response. In-plane cyclic displacement tests were performed on the full-scale reduced size steel frame infilled with two different SIM panels: that with an open gap (type 1) and that without a gap (type 2). Both measure $2.4 \times 2.4 \mathrm{~m}$ and are made of $230 \times 110 \times 76$ $\mathrm{mm}$ topological concrete units [Fig. 4c]. These tests confirmed in-plane response mechanisms. An outof-plane monotonic airbag test was performed after the last cyclic test on the same panel [Fig. 4d]. The out-of-plane displacement capacity of the square type 2 SIM panel was more than 1.5 times the thickness of the panel. Detailed results have been reported by Totoev and Wang (2013). All in-plane 

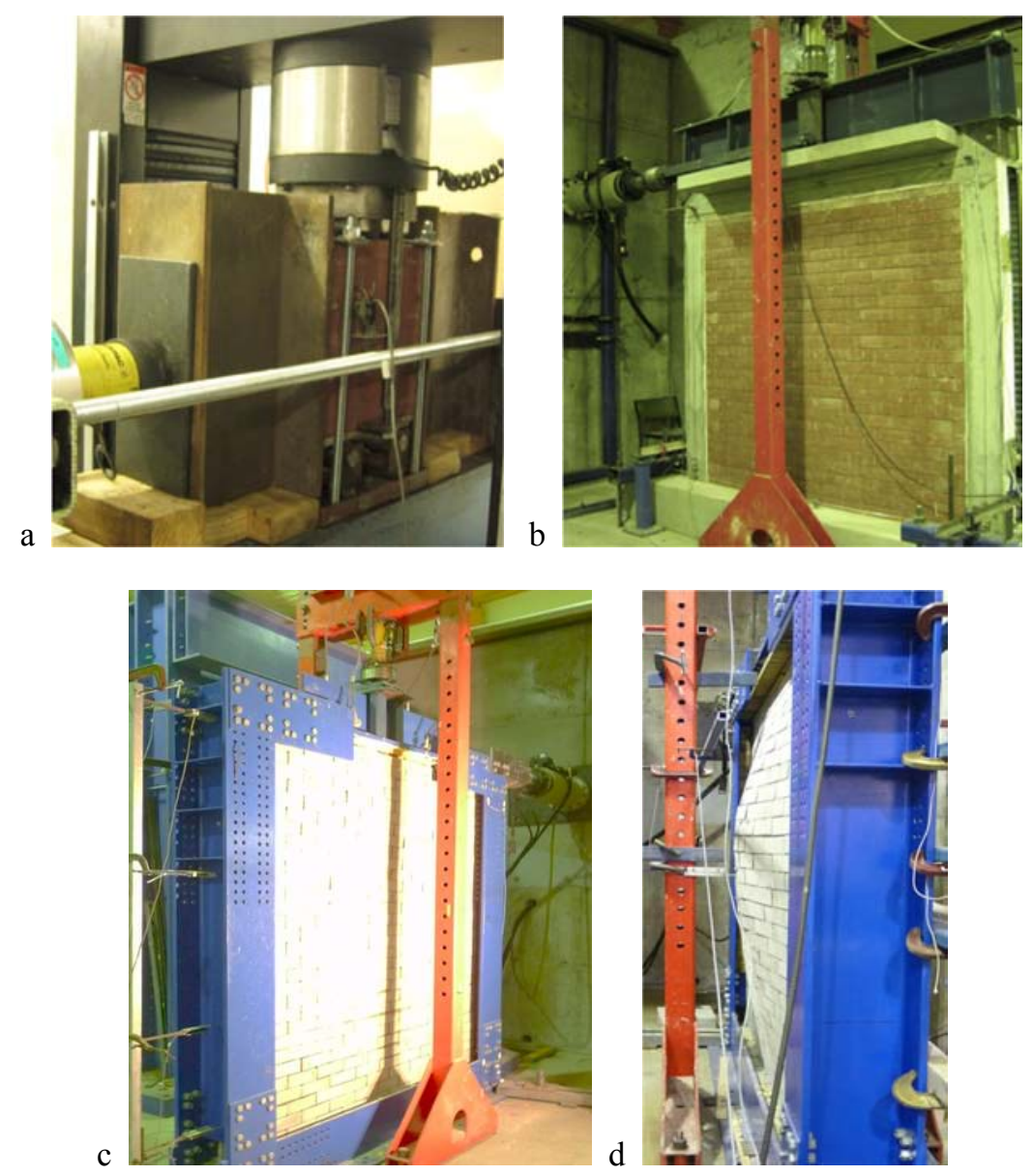

Figure 4. Experimental tests on SIM, with a) Displaying a friction test, b) An in-plane cyclic test on a type 3 panel, c) An in-plane cyclic test on type 1 and 2 panels, and d) An out-of-plane test.

cyclic tests also have provided experimental data for calculation of the frictional energy dissipation and estimation of damping.

\subsection{Numerical Modelling}

Numerical modelling of SIM panels was done using the microstructural approach with DIsplacement ANAlyzer (DIANA) Finite Element (FE) software (Informer Technologies, Inc., Walnut, California, USA) (Witte and Kikstra, 2002) and the super-element approach through the SeismoStruct FE program, Version 6.5 (Seismosoft, Ltd., Pavia, Italy). Both models were verified using experimental results described above. SeismoStruct was selected for numerical simulations for multistorey frames as it is a more practical program.
Four FE models were created for the tree bay four story RC frame, including:

1. RC frame without infill panels,

2. RC frame with type 1 SIM infill panels.

3. RC frame with type 2 SIM infill panels, and an

4. RC frame with traditional URM infill panels.

The first numerical simulation was the nonlinear response due to monotonic load (pushover analysis). This simulation determined the yield, ultimate, and structural displacement ductility for all models. The second numerical simulation was the response history analysis under synthetic earthquake ground motion (Totoev et al. 2014). Figure 5 shows selected results of these numerical simulations. 


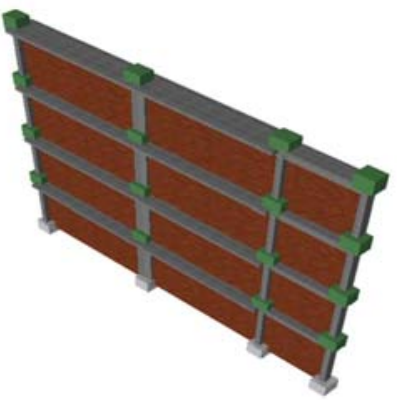

b

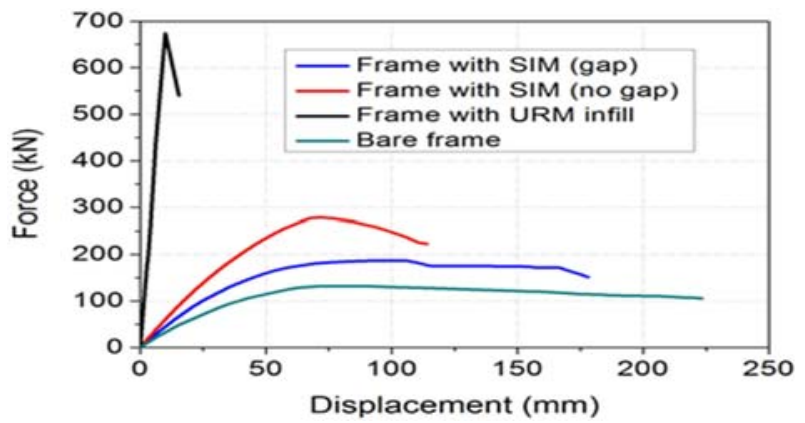

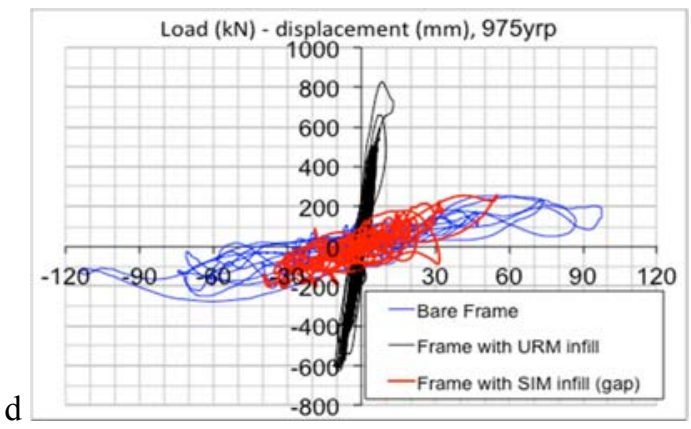

Figure 5. Numerical simulations of a) A FE model, b) Pushover results, c) Synthetic ground acceleration, and d) Response history analysis results (Totoev et al. 2014).

\section{Design Implication of SIM Infill Panel.}

A SIM infill panel is a kind of a wall and as such must be designed to perform typical architectural functions, providing shelter and security, and dividing internal space. Properties such as sound insulation, fire resistance, thermal conductivity, and water penetration, however, are beyond the scope of the following discussion, which will be limited to the engineering design of the SIM infill panel.

It is important to stress that a SIM infill panel is not a frame bracing structure but a mechanical energy dissipation device and must be designed accordingly. A good design procedure for passive energy dissipation devices like a SIM panel is outlined in ASCE FEMA 356 (2000). This document also provides recommendations for testing such devices.

The damping effect afforded by a SIM panel could be calculated as follows:

$$
\zeta_{\text {ef }}=\zeta_{\text {frame }}+\zeta_{S I M}^{*}=\zeta_{\text {frame }}+\frac{U_{S I M}^{F}}{4 \pi U_{\text {frame }}^{S}},
$$

where $\zeta_{e f}$ is the effective damping in the structure, $\zeta_{\text {frame }}$ is the hysteretic damping in the frame only (typically taken as 5\%), $\zeta_{\text {SIM }}^{*}$ is the equivalent viscoelastic damping for SIM panels (about 8.5\%) (Totoev and Lin 2012), $\boldsymbol{U}^{F_{\text {SIM }}}$ is the frictional energy dissipation in all SIM panels during one cycle of vibrations at designed target displacement, and $\boldsymbol{U}^{s}$ frame is the maximum strain energy in the frame.

In the standard procedure of direct displacement-based design, increasing the effective damping of the structure would increase its effective stiffness for the same target displacement. This would allow savings to be made by reducing cross sections and reinforcement of the frame.

\section{Summary of the Structural Benefits of and Problems with SIM Infill Panels}

SIM is a new system which has not yet been used in practice. The majority of the structural benefits of 
SIM listed below were observed during laboratory experiments.

- High frictional energy dissipation,

- High yield displacement and displacement ductility,

- Improved out-of-plane structural integrity,

- Discontinued stress field and, therefore, low tensile stress,

- No shear failure mode-SIM is designed to slide,

- Reduced danger of compressive failure-SIM (type 1) is not load bearing,

- No crack propagation from damaged units (therefore, localized damage),

- Not dependant on the compressive strut action; therefore openings are not critical.

- SIM also has properties, which are of concern. These properties are mostly related to the mortar-less nature of SIM and are perceived rather than observed:

- Consistent dimensions of SIM units were difficult to achieve during prototype unit making in the laboratory conditions. It is expected to be a problem during commercial manufacturing too. As a result, a SIM panel may have gaps up to about $2 \mathrm{~mm}$ wide at the joints;

- The water and air tightness of SIM's joints is expected to be higher than in traditional masonry and in some regions could be of concern;

- $\quad$ SIM does not possess re-centering capabilities. While the slip friction on the joints contributes to the energy dissipation, the static friction could be a cause of small residual structural distortion after an earthquake.

\section{Further Research Directions}

New opportunities in this research area naturally relate to the SIM's problems listed above:

- It would be useful to find/develop a gap filler for SIM joints which could improve the buildability of SIM and its water and air tightness without bonding units into a rigid composite.

- Following the previous point, the friction capacity of joints with gap fillers will need to be reassessed.

- The confining frame could assist with the recentering of SIM panels after an earthquake. A special study would be required to evaluate and compare the strain energy in the frame to the static friction in the SIM.

\section{Conclusion}

In this paper, a review on experimental and numerical studies carried out on semi interlocking masonry (SIM) used as infills wall system for earthquake resistant buildings has been reported. The role of the gap between the SIM wall and the frame girder on the bracing of the building is explained. The paper summarizes the structural benefits and problems of SIM infill walls.

\section{References}

American Society of Civil Engineers (2000), FEMA 356 prestandard and commentary for the seismic rehabilitation of buildings. ASCE for the Federal Emergency Management Agency, Washington, D.C.

Australian Patent Application No. 2010905681, (Filing date Dec. 24, 2010), Mortarless masonry (Newcastle Innovation Limited, Applicant: Totoev, Yuri Z., inventor).

Forghani R, Totoev YZ, Kanjanabootra S (2014), Experimental investigation of the water penetration through semi interlocking masonry (SIM) walls. Proc. of the Annual Meeting of Architectural Institute of Japan, Kobe, Japan 889890.

International Organization for Standardization: Standardization, I.O.F., prEN 1052-3 Methods of test for masonry: Determination of initial shear strength. 1993.

Lin K, Liu H, Zarevich TY (2012), Behavior of mortar-less masonry joint under cyclic shearcompression loading. Research report 44(008), Harbin University 6-10.

Lin K, Totoev YZ, Hong JL (2011), In-plane cyclic test on framed dry-stack masonry panel. Advanced Material Research Journal, 163(167): 3899-3903.

Lin K, Totoev YZ, Liu H (2011a), Energy dissipation during cyclic tests in framed dry stack unreinforced masonry panels. Proceedings of the 9th Australasian Masonry Conference, Queenstown, New Zealand 205-214.

Lourenço PB, Oliveira DV, Roca P, Orduna A (2005), Dry joint stone masonry walls subjected to in-plane combined loading. Journal of Structural Engineering 131(11): 1665-1673. 
Lourenço PB, Ramos LF (2004), Characterization of cyclic behavior of dry masonry joints. Journal of Structural Engineering 130(5): 779-786.

Lourenço PB, Ramos LF, Vasconcelos G (2004), On the cyclic behaviour of stone dry masonry joints. Proceedings of the 13th International Brick/Block Masonry Conference, Madrid, Spain 1049-1058.

Qamaruddin M, Al-Harthy A (2000), Earthquake hazard potential in Oman. Proc. 12 ${ }^{\text {th }}$ World Conference on Earthquake Engineering 12WCEE, paper 1943, Auckland, New Zealand.

Seisomosoft. SeismoStruct, Version 6.5 (2013), A computer program for static and dynamic nonlinear analysis of framed structures." Pavia, Italy.

Totoev YZ, Lin K (2012), Frictional energy dissipation and damping capacity of framed semi-interlocking masonry infill panel. Proc. 15th International Brick/Block Masonry Conference, Florianapolis, Brazil.

Totoev YZ, Wang Z (2013), In-plane and out-ofplane tests on steel frame with SIM infill, Proc. 12th Canadian Masonry Symposium, Vancouver, British Columbia, Canada.

Totoev YZ, Williamson D, Wang Z (2014), Vibrations of multi-storey RC frame with SIM panels; numerical simulation. Proc. $9^{\text {th }}$ International Masonry Conference, Guimaraes, Portugal.
Uzoegbo HC (2003), In-plane and out-plane behaviour of dry-stack block walling systems. Proc., The Ninth North American Masonry Conference, Clemson, South Carolina.

Uzoegbo HC, Senthivel R (2009), An effective retrofitting system for dry-stack masonry subject to seismic loading. The Masonry Society Journal 22(3): 71-84.

Uzoegbo HC, Senthivel R, Ngowi, JV, (2004), Loading capacity of dry-stack masonry walls. The Masonry Society Journal 25(1): 41-52.

Vasconcelos G, Lourenco PB (2009), In-plane experimental behavior of stone masonry walls under cyclic loading. Journal of Structural Engineering 135(10): 1269-1277.

Vasconcelos G, Lourenço PB, Mouzakis H, Karapitta L (2006), Experimental investigations on dry stone masonry walls. Proceedings of the 1st International Conference on Restoration of Heritage Masonry Structures, Cairo, Egypt.

Wang Z, Totoev YZ, Lin K (2014), Experimental study on RC and steel frames with SIM infill. Proceedings of the $9^{\text {th }}$ International Masonry Conference, Guimaraes, Portugal.

Witte FCD, Kikstra WP (2002), DIANA User's Manual. California. p. 38. 